\title{
Pengaruh Pendekatan Matematika Realistik Berbasis Pemecahan Masalah Berbantuan Media Konkret Terhadap Hasil Belajar Matematika
}

\author{
Ni Pt. Utami Dewi Narayani ${ }^{*}$ \\ Pendidikan Guru Sekolah Dasar, Fakultas Ilmu Pendidikan, Universitas Pendidikan Ganesha
}

\author{
A R T I C L E I N F O \\ Article history: \\ Received 10 February \\ 2019 \\ Received in revised form \\ 09 March 2019 \\ Accepted 15 April 2019 \\ Available online 25 May \\ 2019 \\ Kata Kunci: \\ PMR, pemecahan masalah, \\ media konkret \\ Keywords: \\ PMR, problem-solving, \\ concrete media
}

\begin{abstract}
A B S T R A K
Penelitian ini bertujuan untuk mengetahui pengaruh yang signifikan Pendekatan Matematika Realistik berbasis pemecahan masalah berbantuan media konkret terhadap hasil belajar matematika siswa kelas V di Gugus I Kecamatan Banjar Kabupaten Buleleng tahun pelajaran 2017/2018. Penelitian ini adalah penelitian eksperimen semu (quasi experiment), dengan desain penelitian non-equivalent post-test only control group design. Populasi penelitian ini adalah kelas V SD di Gugus I Kecamatan Banjar Kabupaten Buleleng yang berjumlah 134 orang. Sampel penelitian yaitu berjumlah 60 siswa, terdiri dari 30 siswa kelas V SDN 3 Kaliasem sebagai kelompok eksperimen dan 30 siswa kelas V SDN 3 Temukus sebagai kelompok kontrol. Pemilihan sampel menggunakan teknik random sampling. Data hasil belajar matematika dikumpulkan menggunakan metode tes dengan instrumen tes hasil belajar maematika, berbentuk pilihan ganda. Analisis data menggunakan analisis statistik deskriptif dan statistik inferensial uji-t.
\end{abstract}

Perbandingan hasil penghitungan rata-rata skor hasil belajar matematika kelompok eksperimen adalah 19,36 lebih besar dari rata-rata skor hasil belajar matematika kelompok kontrol sebesar 13,70. Hasil analisis data thitung $=9,39$ lebih besar dari tabel= 2,05 taraf signifikan $5 \%$, thitung $>$ trabel sehingga $\mathrm{H}_{0}$ ditolak dan $\mathrm{H}_{1}$ diterima. Hasil penelitian menunjukkan bahwa terdapat pengaruh yang signifikan Pendekatan Matematika Realistik berbasis pemecahan masalah berbantuan media konkret terhadap hasil belajar matematika siswa kelas V di Gugus I Kecamatan Banjar Kabupaten Buleleng tahun pelajaran 2017/2018.

\begin{abstract}
A B S T R A C T
This study aimed at investigating the significant effect of realistic mathematic approach problem solving-based with concrete media towards mathematic achievement in fifth grade of elementary school in Gugus I Kecamatan Banjar Kabupaten Buleleng in academic year 2017/2018. This was a quasi-experimental research utilizing non-equivalent post-test only control group design. There were 134 students from fifth grade Gugus I Kecamatan Banjar Kabupaten Buleleng as the population of this study. The samples of this study were 60 students which consisted of 30 students from fifth grade of SDN 3 Kaliasem as experimental group and 30 students from fifth grade of SDN 3 Temukus as control group. The samples were chosen using random sampling technique. The data of mathematic achievement result collected by using method test with mathematic achievemen tresult test instrument, in from of multiple choice. The obtained data were analysed descriptively and inferentially t-test. The comparison of mean score from experimental and control group reveals that higher score than the control one $(19,36>13,70)$. Hypothesis testing shows that tobserved is higher than $t$ critical value $(9,39>2,05)$ at the level of significance $5 \%$, hence $\mathrm{H}_{0}$ is rejected and $\mathrm{H}_{1}$ is accepted. This indicates that investigating the significant effect of realistic mathematic approach problem solving-based with concrete media towards mathematic achievement in fifth grade of elementary school in Gugus I Kecamatan Banjar Kabupaten Buleleng in academic year 2017/2018.
\end{abstract}

Copyright (C) Universitas Pendidikan Ganesha. All rights reserved. 


\section{Pendahuluan}

Pendidikan matematika di tanah air saat ini sedang mengalami perubahan paradigma. Terdapat kesadaran yang kuat, terutama di kalangan pengambil kebijakan, untuk memperbaharui pendidikan matematika. Tujuannya adalah agar pembelajaran matematika lebih bermakna bagi siswa dan dapat memberikan bekal kompetensi yang memadai baik untuk studi lanjut maupun untuk memasuki dunia kerja (Gazali, 2016).

Matematika merupakan ilmu universal yang mendasari perkembangan teknologi modern saat ini. Mengapa demikian?, karena matematika memiliki peran penting yang menjadi sarana dalam pemecahan masalah kehidupan (Narayani, 2019; Suandito, 2017). Pentingnya matematika dalam pembelajaran mulai dari jenjang sekolah dasar sampai perguruan tinnggi yang berfungsi dalam mengembangkan daya nalar kemampuan berpikir 16 (Amir, 2014; Sholihah \& Mahmudi, 2015; Siagian, 2016). Konsep-konsep dalam matematika yang abstrak tersusun berjenjang dan berurutan masih diperlukan pembuktian-pembuktian khusus, sehingga dalam mempelajari matematika konsep sebelumnya harus dikuasai karena merupakan prasyarat untuk melanjutkan konsep berikutnya(Narayani, 2019). Pembuktian merupakan hal yang sering dilakukan dalam bidang matematika. Pada umumnya masih banyak yang belum mengetahui cara yang digunakan untuk melakukan pembuktian dalam matematika. Berbicara tentang bukti matematika, terkadang kita temui berbagai kalangan, umumnya siswa dan mahasiswa yang cenderung berpikir bahwa bukti tidak begitu penting di dalam mempelajari matematika (Asih, 2019; Purnama et al., 2017). Pada tahap awal pembuktian matematika bukanlah sesuatu yang mudah. Kejadian inilah yang menjadikan seseorang malas untuk memahami bukti dalam matematika (Hernadi, 2013). Dikalangan pelajar dan mahasiswa bukti adalah alat yang hanya digunakan, oleh matematikawan, untuk menjelaskan pernyataan matematika yang telah diketahui kebenarannya (Asih, 2019). Dalam pembuktian matematika terdapat beberapa metode pembuktian sederhana dengan menggunakan aturanaturan logika dasar, misalnya bukti langsung, bukti tak langsung, bukti dengan kontradiksi, bukti ketunggalan, penyanggahan bukti dengan counter example, bukti dengan induksi matematika(Hernadi, 2013). Adapun bukti yang digunakan dapat berupa bukti formal dan bukti informal (Suandito, 2017).

Pada jenjang SD merupakan sebuah pondasi untuk melangkah ke jenjang pendidikan yang lebih tinggi. Hal ini seperti yang tertuang dalam Undang Undang Republik Indonesia (2003) tentang Sistem Pendidikan Nasional pada pasal 17 ayat 1, yaitu "pendidikan dasar merupakan jenjang pendidikan yang melandasi jenjang pendidikan menengah". Sehingga peserta didik pada jenjang SD sudah semestinya dibekali dengan ilmu pengetahuan dasar dan keterampilan dasar. Dalam hal ini keterampilan dasar yang dimaksud adalah mata pelajaran yang tercantum dalam kurikulum SD/MI untuk mengembangkan pengetahuan dan keterampilannya pada jenjang pendidikan selanjutnya. Dalam mengembangkan pengetahuan dan keterampilan peserta didik dapat diperoleh melalui pembelajaran di kelas. Pembelajaran di kelas tidak terlepas dari aktivitas belajar siswa. Melalui aktivitas belajar tersebut diharapkan dapat meningkatkan pengalaman belajar sehingga proses pembelajaran akan menjadi lebih bermakna bagi siswa.

Menurut Ausubel (Didin \& Sari, 2017) pembelajaran bermakna adalah "pengkombinasian materi baru dengan materi yang telah diketahui dalam suatu struktur kognitif". Artinya pembelajaran bermakna merupakan suatu proses mengkaitkan informasi baru pada konsep-konsep relevan yang terdapat dalam struktur kognitif seseorang. Pada proses mencari informasi dalam paradigma baru menekankan pada peserta didik sebagai manusia yang memiliki potensi untuk belajar dan berkembang. Sehingga siswa harus bersifat aktif dalam mengembangkan pengetahuan (Rahmah, 2013). Sejalan dengan pendapat Aristiani (2016) "peserta didik diharapkan dapat aktif dalam belajar, aktif berdiskusi, berani menyampaikan gagasan dan menerima gagasan dari orang lain serta memiliki kepercayaan diri yang tinggi". Keaktifan siswa berada pada tingkat kognitifnya, karena perkembangan kognitif siswa SD berapa pada tahap operasional konkret. Oleh sebab itu siswa SD memandang sesuatu hal secara holistik atau menyeluruh sehingga dalam pembelajaran guru harus mampu menghadirkan dunia nyata ke dalam kelas. Guru bertugas menciptakan rencana yang optimal untuk memperoleh suasana pembelajaran yang aktif, sehingga siswa dapat lebih termotivasi untuk aktif memperoleh pengetahuan dan pengalaman dengan kemampuannya sendiri untuk meningkatkan hasil belajarnya. Salah satu mata pelajaran yang harus dicapai hasil belajarnya yaitu matematika (Artawa et al., 2013; Oktiani, 2017).

Matematika merupakan ilmu dasar untuk mempelajari ilmu-ilmu yang lain (Gazali, 2016). Novitasari (2016) berpendapat bahwa, "pembelajaran matematika merupakan proses psikologis berupa kegiatan aktif dalam upaya seseorang untuk memahami atau menguasai materi matematika". Ada beberapa hal yang perlu mendapat perhatian dalam belajar matematika adalah: (1) pengetahuan harus dibangun oleh siswa secara aktif, (2) belajar lebih ditekankan pada proses bukan hanya pada hasil akhir, (3) fokus dalam proses belajar adalah siswa, dan (4) mengajar adalah membelajarkan siswa. Menurut Fuadi et al. (2016) berpendapat bahwa, tujuan pembelajaran matematika di sekolah dasar adalah 
"memberikan bekal yang cukup bagi siswa untuk menghadapi materi-materi matematika pada tingkat pendidikan lanjutan". Dalam belajar matematika siswa tidak hanya menerima dan menghafalkan konsep atau rumus tetapi siswa harus dapat menemukan sendiri konsep atau rumus tersebut agar bisa bertahan lama dalam ingatannya. Terkait dengan tujuan pembelajaran matematika tersebut, pemecahan masalah dan aktivitas kreatif berperan sangat penting dalam pembelajaran matematika. Hal ini diperkuat oleh pernyataan (Kamarullah, 2017) yang menyatakan bahwa "pada dasarnya, matematika adalah pemecahan masalah karena itu, matematika sebaiknya diajarkan melalui berbagai masalah yang ada di sekitar siswa dengan memperhatikan usia dan pengalaman yang dimiliki siswa". Agar siswa dapat mencapai hasil belajar yang baik dan dapat mengembangkan aktivitasnya dalam pembelajaran maka proses pembelajaran harus dikemas sedemikian rupa dengan memanfaatkan segala potensi yang dimiliki oleh siswa.

Matematika merupakan mata pelajaran yang harus dipelajari oleh siswa mulai dari tingkat SD sampai perguruan tinggi. Tidak hanya dipelajari saja namun matematika juga diperlukan untuk kegiatan sehari-hari dalam memecahkan masalah. Menurut Sriwahyuni et al. (2019); (Wasitohadi, 2014) matematika dipelajari oleh siswa ketika di sekolah untuk membekali mereka dengan beberapa kompetensi antara lain kemampuan berpikir logis, analistis, sistematis, kritis, dan kreatif serta kemampuan bekerjasama. Menurut Purnama et al. (2017) Permainan berhitung merupakan bagian dari matematika, diperlukan untuk menumbuh kembangkan keterampilan berhitung yang sangat diperlukan dalam kehidupan sehari-hari, terutama konsep bilangan yang merupakan juga dasar bagi pengembangan kemampuan matematika. Kompetensi diperlukan supaya siswa memiliki kemampuan memperoleh, mengelola, dan memanfaatkan informasi untuk bersosialisasi dalam kehidupan yang selalu berubah, tidak pasti dan kompetitif (Diana, 2017) Matematika adalah suatu cara untuk menemukan jawaban terhadap masalah yang dihadapi manusia; suatu cara menggunakan informasi, menggunakan pengetahuan tentang betuk dan ukuran, menggunakan pengetahuan tentang menghitung, dan yang paling penting adalah memikirkan dalam diri manusia itu sendiri dalam melihat dan menggunakan hubungan-hubungan (Hasratuddin, 2016).

Namun, saat ini pembelajaran matematika di SD tidak semua dapat terwujud sesuai dengan harapan. Pelajaran matematika di SD masih dianggap bidang studi yang sulit dipahami oleh para siswa. Hal ini disebabkan karena kurangnya pemahaman konsep matematika siswa. Berdasarkan hasil wawancara yang di lakukan pada tanggal 14 dan 15 Januari 2019 dengan 6 guru wali kelas V di SD Gugus I Kecamatan Banjar Kabupaten Buleleng, terkait pembelajaran matematika. Didapatkan hasil wawancara yaitu sebagai berikut: 1) siswa kurang antusias dalam pembelajaran matematika dikarenakan siswa tidak mampu memahami sepenuhnya materi yang diberikan guru. Karena tidak semua materi yang diberikan bersifat rumus dan hafalan tetapi memerlukan suatu penemuan ide untuk memecahkan masalah. 2) Siswa belum memahami konsep dasar matematika, konsep dasar matematika dapat dipahami dengan baik dan benar pada beberapa peserta didik. Jika konsep dasar belum dipahami dengan baik dan benar, maka akan berakibat pada kesalahan pemahaman pada konsep selanjutnya. 3) Siswa pada umumnya mempunyai anggapan bahwa matematika adalah pelajaran yang sulit dan membosankan. Dikarenakan semangat belajar siswa yang kurang disebabkan oleh pembelajaran matematika kurang menarik minat siswa.

Selain wawancara, dilakukan pula observasi lebih lanjut pada tanggal 5 dan 16 Pebruari 2019 mengenai proses pembelajaran dan hasil UAS siswa kelas V pada mata pelajaran matematika di SD Gugus I Kecamatan Banjar Kabupaten Buleleng. Dari hasil observasi diemukan masalah antara lain 1) guru jarang menggunakan pendekatan pembelajaran yang inovatif. Hal tersebut dikarenakan pemahaman guru yang kurang untuk menciptakan proses pembelajaran yang menekankan keaktifan dan interaksi siswa. 2) Kurang antusias siswa dalam mengikuti pembelajaran matematika, dikarenakan siswa tidak mampu memahami sepenuhnya materi yang diberikan guru. 3) Penyampaian pembelajaran yang dikemas kurang menarik perhatian dan minat siswa untuk mempelajari matematika. Hal ini dikarenakan pusat perhatian siswa lebih banyak di luar untuk bermain daripada mengikuti pembelajaran matematika di kelas. 4) dalam proses pembelajaran guru jarang menggunakan media pendukung untuk membantu siswa memahami pembelajaran yang diajarkan.

Dari hasil pencatatan dokumen diperoleh data nilai rata-rata ulangan akhir semester I mata pelajaran Matematika tahun pelajaran 2018/2019 siswa kelas V di Gugus I Kecamatan Banjar hanya $43,2 \%$ siswa yang mencapai KKM, sedangkan siswa yang belum mencapai KKM sebanyak 56,8\% Rendahnya hasil belajar matematika disebabkan proses pembelajaran yang belum optimal. Sehingga benar yang dikatakan Evi (2011) salah satu penyebab rendahnya hasil belajar matematika siswa adalah "dikarenakan belajar matematika siswa belum bermakna, sehingga pengertian siswa tentang konsep sangat lemah". Agar dapat mengoptimalkan hasil belajar dan pembelajaran lebih bermakna, guru dituntut untuk berinovasi dalam pengelolaan proses pembelajaran agar seluruh siswa dapat aktif baik fisik maupun mental selama proses pembelajaran berlangsung. Inovasi tersebut dapat berupa pemilihan pendekatan pembelajaran yang sesuai dengan perkembangan mental siswa dan dibantu dengan 
penggunaan media pembelajaran yang tepat. Turdjai (2016) menyatakan, pendekatan pembelajaran dapat diartikan sebagai titik tolak atau sudut pandang seseorang terhadap proses pembelajaran, yang merujuk pada pandangan tentang terjadinya suatu proses yang sifatnya masih sangat umum. Di dalamnya mewadahi, menginsiprasi, menguatkan, dan melatari metode pembelajaran dengan cakupan teoretis tertentu.

Salah satu pendekatan pembelajaran yang tepat digunakan agar proses pembelajaran matematika menjadi kondusif dan menyenangkan, serta menitikberatkan pada suatu penemuan ide dengan memecahkan masalah realistik yang dapat memunculkan dimensi keberhasilan belajar yaitu menggunakan Pendekatan Matematika Realistik berbasis pemecahan masalah. Menurut Ariyadi (2012) "suatu pengetahuan akan menjadi bermakna bagi siswa jika proses pembelajaran dilaksanakan dalam suatu konteks atau pembelajaran menggunakan permasalahan realistik". Pendekatan Matematika Realistik tepat digunakan dalam pembelajaran matematika, karena siswa terlibat langsung dalam menemukan kembali ide dan konsep matematika melalui eksplorasi masalah-masalah nyata, sehingga pembelajaran menjadi lebih bermakna.

Pembelajaran matematika tidak dapat dipisahkan dari pemecahan masalah. Menurut Polya (dalam Arista et al., 2013) "pemecahan masalah adalah usaha untuk mencari jalan keluar dari suatu kesulitan dalam pembelajaran, mencapai tujuan yang tidak dengan segera dapat dicapai". Dalam pemecahan masalah terdapat strategi-strategi yang digunakan untuk memecahkan masalah. Strategi yang digunakan untuk pemecahan masalah disesuaikan dengan situasi dan kondisi masalah yang disajikan. Untuk memaksimalkan penerapan pembelajaran Pendekatan Matematika Realistik berbasis pemecahan masalah diperlukan penggunaan media pembelajaran. Media yang dapat digunakan untuk memaksimalkan penerapan Pendekatan Matematika Realistik yaitu media konkret. Penggunaan media konkret dapat memberikan pengalaman langsung kepada siswa. Dengan demikian pembelajaran akan menjadi lebih hidup karena dapat memanfaatkan lingkungan sekitar siswa secara optimal sebagai media belajar. Sangat tepat jika dalam pembelajaran matematika di SD menerapkan Pendekatan Matematika Realistik berbasis pemecahan masalah berbantuan media konkret, karena dapat menciptakan kegiatan belajar efektif yang kondusif dan menyenangkan. Sehingga penggunaan Pendekatan Matematika Realistik berbasis pemecahan masalah dalam pembelajaran matematika siswa kelas V SD di Gugus I Kecamatan Banjar Kabupaten Buleleng perlu diterapkan sehingga dapat meningkatkan hasil belajar siswa yang selama ini masih rendah.

Berdasarkan uraian yang telah dipaparkan, perlu diadakan penelitian dengan menggunakan Pendekatan Matematika Realistik berbasis pemecahan masalah berbantuan media konkret untuk membuktikan pengaruhnya terhadap hasil belajar matematika. Adapun judul penelitian ini adalah "Pengaruh Pendekatan Matematika Realistik Berbasis Pemecahan Masalah Berbantuan Media Konkret Terhadap Hasil Belajar Matematika Siswa Kelas V SD Di Gugus I Kecamatan Banjar Kabupaten Buleleng Tahun Pelajaran 2017/2018".

\section{Metode}

Penelitian ini dilaksanakan di SD Gugus I Kecamatan Banjar Kabupaten Buleleng. Jenis penelitian ini adalah eksperimen semu atau quasi eksperiment. Penelitian ini mengikuti rancangan non equivalent post-test only control group design. Secara prosedural desain penelitian ini disajikan dalam tabel 1 berikut.

Tabel 1.Rancangan Eksperimen

\begin{tabular}{llc}
\hline $\mathrm{E}$ & $\mathrm{X}$ & $\mathrm{O}_{1}$ \\
\hline $\mathrm{K}$ & - & $\mathrm{O}_{2}$ \\
\hline & & Sumber: dimodifikasi dari Gall, et al. (Anak Agung Gede, 2014)
\end{tabular}

Populasi dalam penelitian ini adalah seluruh siswa kelas V tahun pelajaran 2017/2018 di SD Gugus I Kecamatan Banjar Kabupaten Buleleng yang berjumlah 134 orang. Sampel adalah sebagian dari populasi yang diambil, yang dianggap mewakili seluruh populasi dan diambil dengan menggunakan teknik tertentu (Anak Agung Gede, 2014). Dalam penelitian ini, teknik sampling yang digunakan adalah teknik cluster random sampling. Data yang dikumpulkan dalam penelitian ini adalah hasil belajar matematika siswa.

Data yang telah didapat kemudian dianalisis dengan menggunakan statistik deskriptif dan statistik inferensial. Teknik analisis statistik deskriptif digunakan untuk mencari mean, median, modus, varians dan standar deviasi (SD). Teknik analisis statistik inferensial yang digunakan adalah uji-t. Sebelum melakukan uji-t, terlebih dahulu dilakukan analisis uji prasyarat yang meliputi uji normalitas dan uji homogenitas. 
Analisis deskriptif digunakan adalah mean, median, modus dan standar deviasi. Skala penilaian untuk menentukan tinggi rendahnya kualitas variabel-variabel tersebut, skor rata-rata (mean) tiap-tiap variabel dikonversikan dengan menggunakan kriteria rata-rata ideal $\left(\mathrm{M}_{\mathrm{i}}\right)$ dan standar deviasi $\left(\mathrm{SD}_{\mathrm{i}}\right)$. Dalam penelitian ini data disajikan dalam bentuk kurva polygon. Sebelum melakukan uji hipotesis dilakukan beberapa uji prasyarat yaitu. 1) Uji Normalitas Data dengan kreteria pengujian data berdistribusi normal jika angka singnifikan (sig.) > 0,05. 2) Uji Homogenitas Varians dengan kreteria data berdistribusi homogenitas jika angka singnifikan (sig.) $>0,05$. Setelah selesai melakukan uji prasyarat maka dilakukan dengan uji hipotesis dengan kreteria jika $t_{\text {hitung }}>t_{\text {tabel }}$ dengan nilai $(s i g)<0,$,05 . Penelitian dilakukan di SD Gugus I Kecamatan Banjar Kabupaten Buleleng dengan rancangan penelitian pada kelas V semester genap tahun pelajaran 2017/2018.

\section{Hasil dan Pembahasan}

Pada Hasil post-test dari 30 siswa pada kelompok eksperimen diperoleh mean $(\mathrm{M})=19,36$, median $(M d)=19,75$, modus $(M o)=20,10$, maka dapat diketuhi nilai Mo $>M d>M$. Hal tersebut berarti sebagai skor kelompok eksperimen cenderung tinggi. Data hasil post-test kelompok eksperimen disajikan dalam Gambar 1

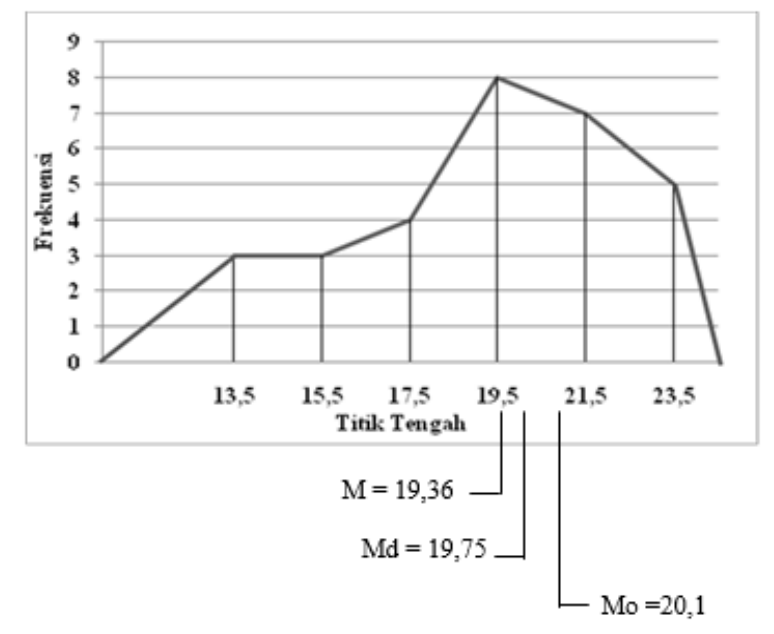

Gambar 1. Grafik Poligon Skor Hasil Belajar Matematika Kelompok Eksperimen

Berdasarkan grafik polygon di atas, diketahui modus lebih besar dari median dan median lebih besar dari mean. Dengan demikian, kurva di atas menunjukan kurva juling negative yang berarti sebagai skor cenderung tinggi. Berdasarkan perhitungan skala lima diperoleh skor rata-rata kelompok eksperimen dengan dibelajarkan Pendekatan Matematika Realistik Berbasis Pemecahan Masalah Berbantuan Media Konkret adalah 19,36 tergolong kriteria sangat tinggi.

Hasil post-test dari 30 siswa pada kelompok kontrol diperoleh mean $(\mathrm{M})=13,70$, median $(\mathrm{Md})=$ 13,50, modus $(\mathrm{Mo})=13,50$, maka dapat diketuhi nilai $\mathrm{Mo}=\mathrm{Md}<\mathrm{M}$. Hal tersebut berarti sebagai skor kelompok kontrol cenderung sedang. Data hasil post-test kelompok kontrol disajikan dalam Gambar 2

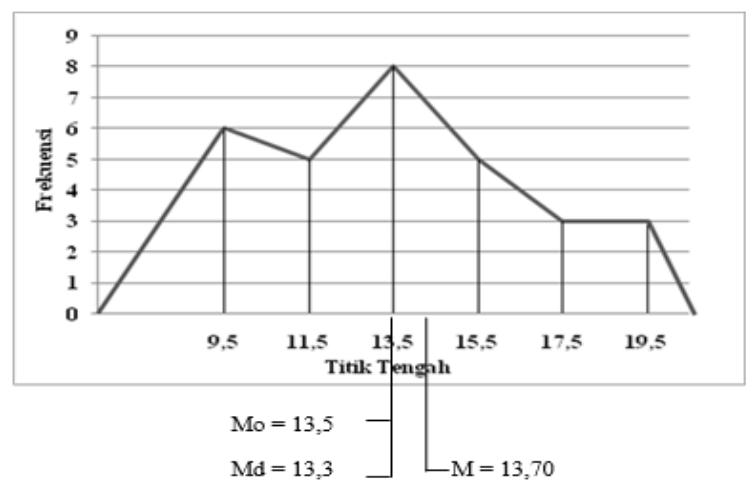

Gambar 2. Grafik Poligon Skor Hasil Belajar Matematika Kelompok Kontrol

Berdasarkan grafik polygon di atas, diketahui modus sama dengan median dan median lebih kecil dari mean. Dengan demikian, kurva di atas menunjukan kurva juling positif yang berarti sebagai skor 
cenderung sedang. Berdasarkan perhitungan skala lima diperoleh skor rata-rata kelompok kotrol dengan dibelajarkan pembelajaran konvensioan adalah 13,70 tergolong kriteria sedang. Sebelum uji hipotesis dilakukan, terlebih dahulu dilakukan pengujian prasyarat terhadap sebaran data yang meliputi uji normalitas dan uji homogenitas.

\section{Uji Normalitas Data}

Uji normalitas data dilakukan terhadap data hasil belajar matematika kelompok eksperimen dan kontrol. Berdasarkan analisis data yang dilakukan, dapat disajikan hasil uji normalitas sebaran data hasil belajar matematika kelompok eksperimen dan kontrol pada Tabel 2.

Tabel 2. Rangkuman Hasil Uji Normalitas Distribusi Data Hasil Belajar Matematika

\begin{tabular}{lllll}
\hline No & Kelompok data hasil belajar matematika & $\chi^{2}$ hitung & $\chi^{2}$ tabel & Status \\
\hline 1 & Post-test Eksperimen & 5,185 & 7,815 & Normal \\
\hline 2 & Post-test Kontrol & 5,122 & 7,815 & Normal \\
\hline
\end{tabular}

Berdasarkan hasil perhitungan dengan menggunakan rumus chi-kuadrat, diperoleh $\chi^{2}$ hitung hasil belajar matematika kelompok eksperimen adalah 5,185 dan $\chi^{2}$ tabel dengan taraf signifikansi 5\% dan dk= 3 adalah 7,815. Sedangkan, untuk data hasil belajar matematika kelompok kontrol, diperoleh $\chi^{2}$ hitung hasil belajar matematika kelompok kontrol adalah 5,122 dan $\chi^{2}$ tabel dengan taraf signifikansi 5\% dan dk $=3$ adalah 7,815. Maka dapat disimpulkan semua data berdistribusi normal.

\section{Uji Homogenitas}

Uji homogenitas dilakukan terhadap varians pasangan antar kelompok eksperimen dan kontrol. Rangkuman hasil uji homogenitas varians antar kelompok eksperimen dan kontrol disajikan pada Tabel 3

Tabel 3. Rangkuman Hasil Uji Homogenitas Varians antar Kelompok Eksperimen dan Kontrol

\begin{tabular}{llll}
\hline Sumber data & $F_{\text {hitung }}$ & $F_{\text {tabel dengan Taraf Signifikansi 5\% }}$ Status \\
\hline $\begin{array}{l}\text { Post-test Kelompok Eksperimen dan } \\
\text { Kontrol }\end{array}$ & 1,04 & 1,85 & Homogen \\
\hline
\end{tabular}

Berdasarkan Tabel 4 diketahui nilai $F_{\text {hitung }}$ 1,04. Sedangkan nilai $F_{\text {tabel }}$ dengan $\mathrm{db}_{\text {pembilang }}=29$, $\mathrm{db}_{\text {penyebut }}=29$, dan taraf signifikansi $5 \%$ adalah 1.85 . Hal ini berarti $F_{\text {hitung }}<F_{\text {tabel }}$ sehingga varians data hasil belajar metematika kelompok eksperimen dan kontrol adalah homogen.

Uji Hipotesis

Berdasarkan uji prasyarat analisis data, diperoleh bahwa data hasil belajar matematika kelompok eksperimen dan kontrol adalah normal dan varians kedua kelompok homogen. Untuk itu, pengujian hipotesis dilakukan dengan menggunakan uji-t sampel independent (tidak berkorelasi) dengan rumus separated varians. Rangkuman hasil perhitungan uji-t antar kelompok eksperimen dan kontrol disajikan pada Tabel 4.

Tabel 4. Rangkuman Hasil Perhitungan Uji-t

\begin{tabular}{lllllll}
\hline Data & Kelompok & $\mathrm{N}$ & 2 & $\mathrm{s}^{2}$ & \multirow{2}{*}{$\mathrm{t}_{\text {hitung }}$} & $\mathrm{t}_{\text {tabel }}$ \\
\cline { 1 - 5 } $\begin{array}{l}\text { Hasil Belajar } \\
\text { Metematika }\end{array}$ & Eksperimen & 30 & 19,36 & 8,65 & \multirow{2}{*}{9,39} & \multirow{2}{*}{2,05} \\
\cline { 2 - 5 } & Kontrol & 30 & 13,70 & 9,69 & & \\
\hline
\end{tabular}

Berdasarkan Tabel hasil perhitungan uji-t di atas, diperoleh nilai thitung sebesar 9.39. Sedangkan nilai tabel dengan taraf signifikansi $5 \%$ adalah 2,002. Hal ini berarti nilai $t_{\text {hitung }}$ lebih besar dari nilai $t_{\text {tabel }}$ (thitung $>t_{\text {tabel}}$ ), sehingga $\mathrm{H}_{0}$ ditolak atau $\mathrm{H}_{\mathrm{a}}$ diterima. Dengan demikian, dapat diinterpretasikan bahwa terdapat pengaruh yang signifikan Pendekatan Matematika Realistik berbasis pemecahan masalah berbantuan media konkret terhadap hasil belajar matematika siswa kelas V tahun pelajaran 2017/2018 di SD Gugus I Kecamatan Banjar Kabupaten Buleleng adalah 19,36 lebih besar dari rata-rata hasil belajar matematika siswa yang mengikuti pembelajaran dengan tidak menggunakan Pendekatan Matematika Realistik berbasis pemecahan masalah berbantuan media konkret sebesar 13,70. Berdasarkan hasil temuan tersebut, dapat disimpulkan bahwa penerapan Pendekatan Matematika Realistik berbasis pemecahan masalah berbantuan media konkret berpengaruh terhadap hasil belajar matematika siswa kelas V tahun pelajaran 2017/2018 di SD Gugus I Kecamatan Banjar Kabupaten Buleleng. 
Berdasarkan deskripsi data hasil penelitian, kelompok siswa yang mengikuti pembelajaran dengan Pendekatan Matematika Realistik berbasis pemecahan masalah berbantuan media konkret memiliki hasil belajar yang lebih tinggi dibandingkan dengan kelompok siswa yang tidak mengikuti pembelajaran dengan Pendekatan Matematika Realistik berbasis pemecahan masalah berbantuan media konkret. Tinjauan ini didasarkan pada rata-rata skor hasil belajar matematika siswa. Rata-rata skor hasil belajar matematika yang mengikuti pembelajaran dengan Pendekatan Matematika Realistik berbasis pemecahan masalah berbantuan media konkret adalah 19,36 berada pada kategori sangat tinggi dan rata-rata skor hasil belajar matematika siswa yang tidak mengikuti pembelajaran dengan Pendekatan Matematika Realistik berbasis pemecahan masalah berbantuan media konkret adalah 13,70 berada pada kategori sedang.

Meningkatnya hasil belajar matematika siswa dengan menggunakan Pendekatan Matematika Realistik berbasis pemecahan masalah berbantuan media konkret disebabkan oleh perbedaan perlakuan dalam proses pembelajaran. Pada proses pembelajaran dipengaruhi oleh beberapa faktor. Beberapa faktor yang menyebabkan adanya pengaruh penerapan Pendekatan Matematika Realistik berbasis pemecahan masalah berbantuan media konkret diantaranya adalah Pertama, siswa melakukan reinvention (penemuan kembali). Penemuan kembali adalah menemukan suatu cara penyelesaian secara informal dalam pembelajaran di kelas. Dalam proses pembelajaran siswa di berikan kebebasan untuk menyusun strategi dalam setiap persoalan yang dihadapi. Hal ini meranmgsang siswa untuk menemukan sendiri hal-hal yang bersifat baru dalam diri siswa mengenai materi matematika. Melalui proses penemuan kembali, siswa mampu mengingat materi lebih lama. Dari proses tersebut terjadi peningkatan hasil belajar matematika siswa. Hal ini didukung oleh Bruner (dalam Putra et al., 2014) mengungkapkan bahwa "dalam pembelajaran matematika, siswa harus menemukan sendiri berbagai pengetahuan yang diperlukannya sehingga pembelajaran dapat lebih bermakna".

Kedua, proses pembelajaran di kelas telah dilakukan oleh guru yaitu menyiapkan permasalahan di dunia nyata. Pada proses pembelajaran di kelas, siswa dapat memahami dan membayangkan permasalahan yang diberikan guru secara seksama, tertib dan pola pikir siswa menjadi tertuju pada topik permasalahan. De Lange (dalam Heruman, 2014) juga menggambarkan proses matematisasi yaitu mematematikakan dunia nyata. Pembelajaran dengan dunia nyata sebagai lingkaran yang tak berujung. Pembelajaran khususnya bagi anak SD yang masih berada pada tahap operasional konkrit, untuk mengajarkan matematika hal pertama yang harus dilakukan oleh guru adalah dengan mengaitkan materi ajar dengan dunia nyata yang dekat dengan anak dalam kehidupan sehari-hari.

Guru dalam pembelajaran menggunakan segala sesuatu yang berada di luar matematika, seperti; kehidupan sehari-hari, lingkungan sekitar, bahkan mata pelajaran lain pun dapat dianggap sebagai dunia nyata. Dunia nyata digunakan sebagai titik awal pembelajaran matematika. Dunia nyata ini dijadikan titik awal pembelajaran misalnya melakukan eksplorasi mengaitkan materi ajar dengan kehidupan sehari-hari (nyata) siswa melalui soal cerita, kemudian matematika dalam bentuk soal cerita di kehidupan nyata ini akan di refleksi (dikaji) oleh siswa untuk mencari tau maksud dari soal cerita tersebut selanjutnya siswa membawa masalah matematika yang telah dikaji secara abstrak tersebut ke dalam bahasa matematika (dalam bentuk operasi hitung ataupun rumus). Hasil eksplorasi siswa tidak hanya bertujuan untuk menemukan jawaban akhir dari permasalahan yang diberikan, tetapi juga diarahkan untuk mengembangkan berbagai strategi penyelesaian masalah yang bisa digunakan.

Ketiga, Pada penelitian ini, Pendekatan Matematika Realistik berbasis pemecahan masalah dibantu dengan menggunakan media konkret. Siswa terlihat sangat antusias dalam proses pembelajaran. Hal tersebut dikarenakan guru menggunakan benda nyata (konkret) sebagai media pembelajaran. Sehingga siswa menjadi lebih mudah mengenal materi bangun datar dan bangun ruang karena dapat melihat langsung bentuk benda tersebut. Media konkret dapat memudahkan guru dalam menyampaikan materi kepada siswa dan siswa lebih mudah memahami materi yang sifatnya abstrak. Selain itu, dengan penggunaan media konkret maka pembelajaran akan lebih menarik perhatian siswa, bahan pelajaran lebih jelas maknanya, metode mengajar akan lebih bervariasi, dan siswa dapat lebih banyak melakukan kegiatan belajar dan tidak hanya mendengarkan penjelasan guru saja, Sudjana \& Rivai (dalam Ni Ny et al., 2017).

Keempat, Selama proses pembelajaran di kelas, siswa terlihat aktif dalam menjawab dan menyelesaikan masalah secara individu maupun kelompok. Hal tersebut terlihat saat siswa mengerjakan LKS yang diberikan guru. Dalam pembelajaran siswa dibagi menjadi kelompok kecil secara heterogen. Hal tersebut bertujuan agar dapat membantu siswa yang lemah dalam proses pembelajaran. Selain itu, dengan pembentukan kelompok yang heterogen siswa akan saling berinteraksi dan bekerjasama dengan anggota kelompok untuk dapat memahami materi yang dipelajari. Siswa berinteraksi dengan guru dan siswa lain mampu menumbuhkan kerjasama dalam proses pembelajaran, sehingga siswa tidak merasa takut untuk bertanya kepada guru jika menemukan permasalahan. Hal ini sesuai dengan pendapat Made (2010) 
bahwa, penerapan strategi yang dipilih dalam pembelajaran matematika haruslah mampu mengoptimalisasikan interaksi seluruh anggota dalam kelas.

Berdasarkan hal di atas maka dapat disimpulkan bahwa keunggulan menggunakan pendekatan matematika realistik berbasis pemecahan masalah adalah sebagai berikut: (1) Untuk mempermudah siswa dalam belajar matematika dan siswa mempunyai strategi dalam memecahkan masalah matematika. (2) Agar siswa dapat mengembangkan pengetahuan yang dimilikinya secara penuh dengan mengaitkan pembelajaran secara nyata dengan kehidupan nyata siswa. (3) Supaya siswa mengetahui betapa menyenangkan mempelajari matematika dengan menggunakan benda konkret. (4) dan dengan memberikan kesempatan berkelompok atau mandiri, siswa dapat berinteraksi dengan guru dan temanteman sekelasnya di dalam pelaksanaan pembelajaran.

Berbeda halnya dengan penerapan pembelajaran di kelas tanpa menggunakan Pendekatan Matematika Realistik berbasis pemecahan masalah berbantuan media konkret, guru cenderung lebih aktif sebagai sumber informasi bagi siswa dan siswa cenderung pasif dalam mengikuti pembelajaran. Guru lebih banyak mendominasi kegiatan pembelajaran. Penjelasan yang diberikan oleh guru masih berorientasi pada buku dan guru jarang mengaitkan materi yang dibahas dengan masalah-masalah nyata yang ada dalam kehidupan sehari-hari Siswa berperan sebagai pendengar yang pasif dan mengerjakan apa yang disuruh guru serta melakukannya sesuai dengan yang dicontohkan. Antar siswa sangat jarang terjadi interaksi. Pemahaman yang diperoleh siswa tentunya tidak akan bertahan lama diingatan siswa karena pemahaman tersebut hanya berdasarkan informasi guru dan tidak diperolehnya dengan pengalaman sendiri.

Hal ini menyebabkan siswa cenderung menghapalkan setiap konsep yang diberikan tanpa memahami dan mengkaji lebih lanjut dari konsep-konsep yang diberikan. Kurang pahamnya siswa terhadap materi yang diberikan akan berpengaruh terhadap hasil belajar Matematika siswa itu sendiri. Ketika siswa diberikan soal maka siswa akan mengalami kesulitan dalam memahami, merencanakan tindakan, dan menentukan konsep-konsep yang akan digunakan untuk memecahkan masalah yang diberikan. Hal ini akan menyebabkan hasil belajar matematik siswa menjadi tidak optimal.

Hasil penelitian yang diperoleh pada penelitian ini juga sejalan dan mendukung penelitian yang dilakukan oleh (Sriwahyuni et al., 2019). Dalam penelitiannya terdapat pengaruh yang signifikan hasil belajar matematika siswa ditinjau dari pembelajaran menggunakan pendekatan pendidikan matematika realistik berbantuan origami dibandingkan dengan pembelajaran matematika konvensional terhadap siswa kelas V SD di Desa Les. Penelitian ini merupakan penelitian eksperimen berbentuk Post-test Control Group Design. Hasil penelitian menunjukan, terdapat pengaruh peningkatan hasil belajar matematika siswa yang signifikan. Peningkatan hasil belajar matematika siswa dengan pendekatan pendidikan matematika realistik berbantuan origami lebih tinggi dibandingkan dengan pembelajaran matematika konvensional.

Dengan demikian, maka terbukti bahwa terdapat pengaruh yang singnifikan Pendekatan Matematika Realistik berbasis pemecahan masalah berbantuan media konkret terhadap hasil belajar matematika pada siswa kelas V SD di Gugus I Kecamatan Banjar Kabupaten Buleleng tahun pelajaran $2017 / 2018$.

\section{Simpulan dan Saran}

Berdasarkan hasil pengujian hipotesis dan pembahasan, maka simpulan penelitian ini menyatakan bahwa terdapat perbedaan hasil belajar matematika yang signifikan antara siswa yang mengikuti pembelajaran dengan Pendekatan Matematika Realistik berbasis pemecahan masalah berbantuan media konkret dan siswa yang mengikuti pembelajaran dengan tidak menggunakan Pendekatan Matematika Realistik berbasis pemecahan masalah berbantuan media konkret. Kualifikasi hasil belajar siswa yang mengikuti pembelajaran dengan Pendekatan Matematika Realistik berbasis pemecahan masalah berbantuan media konkret berada pada kategori tinggi sedangkan hasil belajar siswa yang mengikuti pembelajaran dengan tidak menggunakan Pendekatan Matematika Realistik berbasis pemecahan masalah berbantuan media konkret berada pada kategori sedang. Perbandingan hasil perhitungan rata-rata hasil belajar matematika dengan mengikuti Pendekatan Matematika Realistik berbasis pemecahan masalah berbantuan media konkret adalah 19,36 lebih besar dari tidak mengikuti Pendekatan Matematika Realistik berbasis pemecahan masalah berbantuan media konkret sebesar 13,70.

Saran yang dapat disampaikan berdasarkan penelitian yang telah dilakukan adalah 1) Siswa di sekolah dasar agar lebih aktif dalam mengikuti pembelajaran dan terus mengembangkan pemahamannya dengan berpikir secara sistematis untuk memecahkan masalah yang dihadapi serta selalu bersemangat dalam mengikuti pembelajaran. 2) Guru di sekolah dasar, khususnya yang mengajar matematika dalam proses pembelajaran agar menggunakan Pendekatan Matematika Realistik berbasis pemecahan masalah berbantuan media konkret sebagai salah satu alternatif untuk meningkatkan hasil belajar matematika 
siswa. 3) Kepala sekolah di sekolah dasar agar memberikan informasi dan memfasilitasi para guru agar mampu menggunakan model pembelajaran yang lebih inovatif untuk meningkatkan hasil belajar matematika siswa, sehingga mutu pendidikan sekolah dapat meningkat. 4) Peneliti lain agar dijadikan sebagai acuan kepustakaan untuk penelitian, serta hasil penelitian ini dapat dipakai bahan pertimbangan dalam melakukan penelitian yang sejenis ataupun pada variabel yang berbeda.

\section{Daftar Rujukan}

Amir, A. (2014). Pembelajaran Matematika SD dengan Menggunakan Media Manipulatif. Forum Paedagogik, VI(01), 72-89.

Anak Agung Gede, A. (2014). Metodologi Penelitian Pendidikan. Adiya Media Publishing.

Arista, P. R., Japa, I. G. N., \& Nym, D. (2013). PENGARUH IMPLEMENTASI MODEL PEMBELAJARAN TADIR TERHADAP KEMAMPUAN PEMECAHAN MASALAH MATEMATIKA SISWA KELAS V SD GUGUS XV KECAMATAN BULELENG. 1.

Aristiani, R. (2016). Meningkatkan Percaya Diri Siswa Melalui Layanan Informasi Berbantuan Audiovisual. Jurnal Konseling Gusjigang, 2(2), 182-189. https://doi.org/10.24176/jkg.v2i2.717

Ariyadi, W. (2012). Pendidikan Matematika Realistik Suatu Alternatif Pendekatan Pembelajaran Matematika (Edisi Pert). Graha Ilmu.

Artawa, R., Wyn, ign i, \& Suwatra. (2013). Pengaruh Model Pembelajaran Kooperatif Tipe Make a-Match Terhadap Prestasi Belajar Matematika Siswa Kelas V Sd di gugus 1 kecamatan selat. Mimbar PGSD, 1, 1-10. https://ejournal.undiksha.ac.id/index.php/JJPGSD/article/view/837/710

Asih, S. K. (2019). Keefektifan Model Pembelajaran Realistic Mathematics Education (RME) Terhadap Kemampuan Pemecahan Masalah Matematika. Thinking Skills and Creativity Journal, 2(2), 103-110. https://doi.org/10.23887/tscj.v2i2.21888

Diana. (2017). PEMANFAATAN ICT DALAM PEMBELAJARAN MATEMATIKA BAGI ANAK USIA DINI. Jurnal Unsyiah, 1-10. http://journal.unnes.ac.id/nju/index.php/edukasi/article/download/963/900

Didin, S., \& Sari, M. (2017). P Enerapan M Odel P Embelajaran B Erbasis M Asalah Pada. Jurnal Pendidikan Islam, 6(2), 173-194.

Evi, S. (2011). Pendekatan Matematika Realistik (PMR) untuk Meningkatkan Kemampuan Berfikir Siswa di Tingkat Sekolah Dasar. Jurnal Penelitian Pendidikan, Edisi Khus(2), 154-163.

Fuadi, R., Johar, R., \& Munzir, S. (2016). Peningkatkan Kemampuan Pemahaman dan Penalaran Matematis melalui Pendekatan Kontekstual. 3(1), 47-54. https://doi.org/10.24815/jdm.v3i1.4305

Gazali, R. Y. (2016). Pembelajaran Matematika Yang Bermakna. Math Didactic: Jurnal Pendidikan Matematika, 2(3), 181-190. https://doi.org/10.33654/math.v2i3.47

Hasratuddin. (2016). Membangun Karakter Melalui Pembelajaran Matematika. Jurnal Pendidikan Matematika PARADIKMA, 6(2), 130-141.

Hernadi, J. (2013). Metoda Pembuktian dalam Matematika. Jurnal Pendidikan Matematika, 2(1), 1-13. https://doi.org/10.22342/jpm.2.1.295.

Heruman. (2014). Model Pembelajaran Matematika Di Sekolah Dasar. Remaja Rosdakarya.

Kamarullah. (2017). Pendidikan Matematika Di Sekolah Kita. Al Khawarizmi: Jurnal Pendidikan Dan Pembelajaran Matematika, 1(1), 21-32.

Made, W. (2010). Strategi Pembelajaran Inovatif Kontemporer. Bumi Aksara.

Narayani, N. P. U. D. (2019). Pengaruh Pendekatan Matematika Realistik Berbasis Pemecahan Masalah Berbantuan Media Konkret Terhadap Hasil Belajar Matematika. Jurnal Ilmiah Sekolah Dasar, 3(2), 220. https://doi.org/10.23887/jisd.v3i2.17775

Ni Ny, W., Ni Wyn, R., \& Nym, K. (2017). Pengaruh Model Pembelajaran Tai Berbantuan Media Powerpoint Terhadap Hasil Belajar Bahasa Indonesia Siswa Kelas V. MIMBAR PGSD Undiksha, 5(2). https://doi.org/10.23887/jjpgsd.v5i2.10737

Novitasari, D. (2016). Pengaruh Penggunaan Multimedia Interaktif Terhadap Kemampuan Pemahaman Konsep Matematis Siswa. FIBONACCI: Jurnal Pendidikan Matematika Dan Matematika, 2(2), 8. https://doi.org/10.24853/fbc.2.2.8-18

Oktiani, I. (2017). Kreativitas Guru dalam Meningkatkan Motivasi Belajar Peserta Didik. Jurnal Kependidikan, 5(2), 216-232. https://doi.org/10.24090/jk.v5i2.1939

Purnama, M. dwi, Irawan, E. bambang, \& Sa'dijah, C. (2017). Pengembangan Media Box Mengenal Bilangan Dan Operasinya Bagi Siswa Kelas 1 di SDN Gadang 1 Kota Malang. Jurnal Kajian Pembelajaran Matematika, 1(1), 46-51. https://media.neliti.com/media/publications/102724-ID-pengembanganmedia-box-mengenal-bilangan.pdf

Putra, N. T. A., Suarjana, I. M., \& Japa, I. G. N. (2014). Pengaruh Pendekatan Pendidikan Matematika Realistikberbantuan Origami Terhadap Hasil Belajar Matematikasiswa Kelas V Sddi Desa Les Kecamatan Tejakula Tahun Pelajaran 2013/2014. Mimbar PGSD, 2(1).

Rahmah, N. (2013). BELAJAR BERMAKNA AUSUBEL. Al-Khwarizmi, 1, 43-48. 
Sholihah, D. A., \& Mahmudi, A. (2015). KEEFEKTIFAN EXPERIENTIAL LEARNING PEMBELAJARAN MATEMATIKA MTs MATERI BANGUN RUANG SISI DATAR. Jurnal Riset Pendidikan Matematika, 2(2), 175. https://doi.org/10.21831/jrpm.v2i2.7332

Siagian, M. D. (2016). Kemampuan koneksi matematik dalam pembelajaran matematika. MES: Journal of Matematics Education and Science2, 2(1), 58-67.

Sriwahyuni, T., Maya, R., \& Amelia, R. (2019). Jurnal Kajian Pembelajaran Matematika. Jurnal Pendidikan, 3(April), 18-23.

Suandito, B. (2017). Bukti Informal Dalam Pembelajaran Matematika. Al-Jabar : Jurnal Pendidikan Matematika, 8(1), 13. https://doi.org/10.24042/ajpm.v8i1.1160

Turdjai. (2016). Pengaruh Pendekatan Pembelajaran terhadap Hasil Belajar Mahasiswa. Triadik, 15(2), 17-29. https://ejournal.unib.ac.id/index.php/triadik/article/download/2865/1373

Undang Undang Republik Indonesia, (2003). http://simkeu.kemdikbud.go.id/index.php/peraturan1/8uu-undang-undang/12-uu-no-20-tahun-2003-tentang-sistem-pendidikan-nasional

Wasitohadi, W. (2014). HAKEKAT PENDIDIKAN DALAM PERSPEKTIF JOHN DEWEY Tinjauan Teoritis. Satya Widya, 30(1), 49. https://doi.org/10.24246/j.sw.2014.v30.i1.p49-61 